\title{
Application of Cooperative Learning Type Stad and Hands on Activity to Student Achievement and Learning Activities
}

\author{
Laxmi Zahara $^{1 *}$ and Bq. Siti Maryam ${ }^{2}$ \\ ${ }^{1,2}$ Physics Education Study Program, Faculty of Mathematics and Natural Sciences, Hamzanwadi University, East \\ Lombok, Indonesia \\ *Corresponding author. Email: laxmizahara3@gmail.com
}

\begin{abstract}
This research applies STAD Cooperative Learning Type with Hands on Activity to improve student learning outcomes and student learning activities on the subject of elasticity and Hooke's law in class XI SMAN 1 Selong in the 2019/2020 academic year. This research is a classroom action research. Data collection techniques used are tests and observation sheets. Data analysis in this study used descriptive statistics with a quantitative approach. Based on the research results, it can be concluded that the application of STAD type cooperative learning with Hands on Activity can improve student learning outcomes and learning activities. The score of student activeness working on the LKPD reached a maximum value (100) in cycles I and II. The score of cooperative activeness increased from low (50) to high (77). The score for the activeness of expressing opinions increased from moderate (53) to high (78) Student learning outcomes in elasticity material increased from classical completeness $87 \%$ to $91 \%$.
\end{abstract}

Keywords: STAD cooperative type, Hands on Activity

\section{INTRODUCTION}

The learning paradigm changes along with the development of science and technology. Thus the teacher must change the learning pattern to suit the demands of the times. 21 st century skills consist of three main components, namely: 1) learning skills and innovation (a. Creativity and innovation, b. Critical thinking and problem solving, c. Communication and collaboration); 2) Information, media and technology skills (a.information literacy, b. Media literacy, c. Information media literacy), and 3). Life and career skills (a. Flexible and able to adapt, b. Have initiative and self-direction, c. Have social and cross-cultural abilities, d. Productive and accountable) (Chaeruman 2018). Thus in the application of learning, teachers should pay attention to skills that are in accordance with the needs of the 21 st century.

The curriculum is a set of plans and arrangements regarding the objectives, content, and learning materials and methods used as guidelines for implementing learning activities to achieve certain educational goals. The 2013 curriculum emphasizes a balance between attitudes, knowledge and skills (Kemdikbud 2013). Thus, applied learning should pay attention to aspects of attitude, knowledge and skills. However, this is not the case with research conducted by Palupi (2019), namely learning activities have not focused on students, which still does not reflect Teaching and Learning Activities with the 2013 Curriculum. This can be proven from the information presented by sources and informants who stated difficulties in making adjustments to curriculum changes (Palupi 2019).

Based on the results of observations made at SMAN 1 Selong, students have been actively carrying out learning activities. It's just that there are some people who still look passive, that is, they only pay attention and don't participate in discussion activities. Group performance scores vary between groups. Some did not reach the classical completeness criteria, namely classical completeness only reaching $70 \%$. Thus a learning model is needed that can improve student learning achievement and activeness including: active work on Student Activity Sheets, active discussion, and active collaboration.

Based on the varying conditions of students, namely having diversity in initial grades, in this case the second author as a teacher at school has formed groups heterogeneously based on students' cognitive abilities, so the learning model that is most suitable for overcoming problems in class is the cooperative learning model Type STAD combined with Hamds on Activity. In accordance with the needs of the $21 \mathrm{st}$ century, namely collaborative abilities, flexibility and ability to adapt, have initiative, self-direction, and have 
social abilities, Cooperative learning with Hands on Activity can contain these skills.

The Hands On Activity learning model is defined as a learning model that involves direct activity and experience with natural phenomena or educational experiences that actively involve students in observing an object to gain knowledge or understanding (Nurlatifah 2016). The hands-on activity learning steps in this study are adjusted to the stages of the STAD Cooperative Learning Model, which are as follows: a.) Questions of apperception (questioning and constructivism), namely learning begins by asking questions to explore students' initial knowledge which is able to increase the activity of asking questions and answer to students, b) Formation of a heterogeneous learning community to overcome low student cooperation activities in science learning, c.) Providing modeling, namely observing pictures, cutting and pasting them on Student Activity Sheets, d.) Assessment Student performance (authentic assessment) is carried out during the learning process by the teacher to increase student activity in actively working on Student Activity Sheets, the ability to work together and the ability to express opinions, e.) The conclusion is that learning ends by inviting students independently. $\mathrm{i}$ in providing conclusions on the learning that has been done which is related to the initial knowledge possessed (constructivism). As well as the teacher provides reflection to straighten the actual concept of the material.

STAD learning model is a learning model that really involves students to learn in heterogeneous groups (level of achievement, gender, culture, and ethnicity) consisting of 4-5 students. Learning activities begin with the delivery of learning objectives, delivery of material, group activities, quizzes, and group awards (Anonymous 2016). The STAD cooperative learning model has a section, namely a quiz at the end of the lesson. Through this activity, after students work together in groups, students will take individual tests and separate seats from the initial group. The final test scores will be combined to determine the most active and rewarded group. Educational evaluation is an assessment of the performance of education that has been running in order to obtain information that will later be used to improve things that really need to be improved in education performance (Trisnamansyah 2015). Based on this definition of evaluation, according to the steps to be carried out in Classroom Action Research, namely the process of implementing learning will be evaluated to improve educational performance.

The purpose of this study was to improve student achievement and learning activities through Cooperative Learning Type STAD with Hands on Activity. In accordance with the research conducted by Hariri, namely with hands-on activity students gain experience and appreciation of the concepts in learning and encourage student curiosity more deeply (Hariri 2015). Another study was conducted by Lovisia with the conclusion of obtaining the completeness of student learning achievement and increasing student learning activities by applying the STAD type cooperative learning (Lovisia 2019).

\section{METHOD}

This type of research is qualitative research, namely classroom action research. Classroom Action Research is a form of research that occurs in the classroom in the form of certain actions taken to improve the teaching and learning process in order to improve learning outcomes that are better than before (Riadi 2019). The population in this study were students of class XI IPA 1 at SMAN 1 Selong, totaling 36 students. This study aims to see the increase in students' physics learning achievement in the elasticity material. Classroom action research procedures carried out are: a) planning; b) implementation; c) observation; and d) reflection.

\section{RESULTS AND DISCUSSION}

Cycle I

Planning

Planning for Lecturer Assignment activities in Schools is carried out long before the implementation of learning. On July 18, the teacher and the lecturer team gathered together to discuss the problems faced by students in class when learning physics took place. The teacher expressed the difficulty, namely facing several students who were not active while working on Student Worksheets. The teacher has implemented a group discussion pattern, and varies the group for each change of basic competencies. However, the results obtained by these students did not contribute to group activities. Based on the results of observations of the implementation of learning on July 24 and 25, 2109, when the teacher taught and the lecturer was the observer, most students actively worked on the Student Activity Sheet regarding the rigid object balance material. However, there are some students who tend to be only observers in group work. In other words, there is a gap in the ability of team members in one group. Therefore, we propose to apply a cooperative learning model. The cooperative model that we will apply is cooperative Type STAD with Hands on Activity. Student activity (Hands on Activity) in this study was developed by making student worksheets that are somewhat different from usual, in which students are given pieces of pictures to be cut and then attached to fit the concept of elasticity. From these pictures, students 
must be smart in choosing images that fit the concept of elasticity because not all images are elastic objects

\section{Action}

Cycle I was held on Wednesday, August 72019 at 7:15 am in class XI IPA 1 elasticity material. The learning that is applied is the cooperative type STAD with six phases that are carried out sequentially including: 1) conveying learning objectives, at this stage the teacher conveys the learning objectives, namely the definition of elasticity objects, stress differences, stretch and elastic modulus; 2) conveying information, at this stage the teacher brings rubber balloons and plasticine. The teacher asks one of the students to come to the front of the class to apply force to the two objects, the rubber balloon can return to its original shape, while the plasticine cannot return to its original shape. From these activities, students are asked to conclude the definition of plastic and elastic objects; 3) organize students in groups, at this stage the teacher divides students into 9 groups of 4 people; 4) guiding groups, the teacher directs students to understand the meaning of the questions on the Student Activity Sheet; Each student in the group gets a different question. Students cut pictures, select and paste pictures of elastic objects 5) evaluate learning outcomes, at this stage the teacher asks students to sit separately from their groups and give test questions individually and 6) give awards. In making Student Worksheets, there are different questions in one group that must be done by each group member. Each team must ensure that all team members have worked on the problems and mastered them before working on the quiz. The value of the quiz will be combined in one team to determine the 2 best teams. Thus it is hoped that each group member will cooperate with each other and ensure that all team members master the material in order to get the highest score.

\section{Observation}

Based on observations of students' activeness working on the Student Activity Sheet, they reached a score of 100. However, the scores for the activeness of collaborating and expressing low opinions were 50 and 53. Students distinguished plastic and elastic objects by sticking pictures on the prepared paper. In this activity, students can share assignments with team members.

\section{Reflection}

Based on the implementation of learning in cycle I, the activity of students working on the Student Activity Sheet is very high, this is because each student gets different questions in one group. When cutting pictures on the Student Activity Sheet it takes a long time. Meanwhile, the activeness of working together and expressing low opinions, namely with an average score of 50 and 53, is categorized as low and medium.

The education unit can choose each subject to have a different KKM. For example, the MIPA (Mathematics and Natural Sciences) families have a KKM of 70, the language families (Indonesian and English) have a KKM of 75, the social families (IPS and PPKn) have a KKM of 80, and so on (Anonymous 2018). For the subject of physics on elasticity material has a KKM 75. Individual test scores of students get an average score of 89 with a level of completeness of $87 \%$. Each student is said to have completed individual learning) if the proportion of students' correct answers is $\geq 65 \%$, and a class is said to have completed learning (classical completeness) if in the class there are $\geq 85 \%$ of students who have completed learning (Anonymous 2014). Thus the students' scores in cycle I have been completed, but student activities on the ability to work together and the ability to express opinions must be improved.

\section{Cycle II}

Planning

Based on the results of reflection on the ability to work together and express low opinions. So what is done in the next cycle is to make two types of problems in one group. Two people in one group get the same question, this is done so that students can work together and express opinions. In order for students to work on the Student Activity Sheet more quickly, the pictures provided have been cut out first so that students only need to choose and paste the appropriate picture according to the hooke law application.

\section{Action}

Cycle II was held on Wednesday, August 14, 2019 in class XI IPA 1 on Hooke's law material. The learning that is applied is cooperative type STAD with six phases that are carried out sequentially including: 1) conveying learning objectives, at this stage the teacher conveys the learning objectives, namely explaining Hooke's law statement, analyzing the effects of stress, strain, spring constants and elastic modulus based on graphs; 2) conveying information, at this stage the teacher brings a spring and a load of different masses, students are asked to determine the relationship between the increase in the length of the spring and the load variation. Students can define Hooke's law statement, namely the increase in the length of the spring is proportional to the applied force. 3) organize students in groups, at this stage the teacher divides students into 9 groups of 4 people; 4) guiding groups, the teacher directs students to understand the meaning of the questions on the Student Activity Sheet; two students in one group work on the same problem, because one group gets two types of 
questions. To work on the Student Activity Sheet in cycle 2 , students are faster because they only need to choose a picture and paste it. 5) evaluating learning outcomes, at this stage the teacher asks students to sit separately from their groups and give individual test questions 6) give awards, at this stage the teacher announces the two best groups and is given a prize.

\section{Observation}

Based on observations of student activeness working on Worksheets Students achieved an average score of 100 . The score of the ability to work together increased from an average of 50 to 75 . The score for the ability to express opinions increased from an average of 53 to 75 .
Students pasted a picture of Hooke's law application on the paper already provided. There are several pictures that students must choose. In this activity, students can share tasks with team members. The students' mean score on the indicator explains Hooke's law, concluding that objects that are more plastic or elastic based on stress, strain and elastic modulus data reach a completeness level of $91 \%$.

Reflection

Based on the results of observations, learning was carried out according to plan. The following shows the data on learning outcomes and student activeness from cycle I to cycle II.

Table 4.1 Increasing the Activity Score and Classical Completeness

\begin{tabular}{lll}
\hline Information & Cycle I & Cycle II \\
\hline Classical Completeness & $87 \%$ & $91 \%$ \\
\hline Average value & 81 & 90 \\
\hline Activeness in working on LKPD & 100 & 100 \\
\hline Teamwork Ability & 50 & 75 \\
\hline Ability to express opinions & 53 & 75 \\
\hline
\end{tabular}

Based on Table 4.1, it can be concluded that the application of STAD type cooperative learning with Hands on Activity can improve student learning outcomes and learning activities. The score of student activeness working on the LKPD reached an average value (100) in cycles I and II. The score of cooperative activeness increased from the low category (50) to the high category (70). The score for the activeness of expressing opinions increased from the medium category (53) to the high category (78). Student learning outcomes on elasticity material increased from $87 \%$ classical completeness to $91 \%$.

In this study, using a collaborative approach that aims for students to build their knowledge through dialogue, sharing information among students and teachers so that students can improve mental abilities at a high level. This model is used in every subject, especially those that may develop sharing of information among students. students work together to solve the same problem, and not individually solve separate parts of the problem. Thus, during collaboration, students work together to build the same understanding and concept to solve each part of the problem or task (Safitri 2020). The score of cooperative activeness increased from the low category (50) to the high category

The aspects that are assessed in student learning activities are the activeness of working on LKPD, the ability to work together and the ability to express opinions. Collaboration can make heavy work lighter and faster, foster a sense of togetherness and strengthen brotherhood, can foster a sense of social and care for others, can avoid being selfish or selfish, and generate new ideas or ideas based on the results of discussions during work (Anon 2020).

Apart from the ability to work together, another aspect studied is the ability to communicate. In the 21 st century, the ability to communicate is very important in line with the demands of the 2013 curriculum, which emphasizes the main aspects of attitude, so communication skills need to be improved. Because according to research conducted by Wilhalminah, et al, there is an influence of communication skills on students' moral development (Wilhalminah A., Rahman 2017)

Based on the results of observations and reflections in cycles I and II, it was concluded that cooperative learning type STAD with Hands on Activity can improve student learning outcomes and learning activities. The same results were obtained from research conducted by Anggraeni, namely the application of hands on activities and the example non example method can increase student activity and learning outcomes (Anggraeni 2009). In addition, research conducted by Fathir and Sabrun shows that the application of the Hands on Activity model can improve student learning outcomes (Fathir and Sabrun 2015). In addition, research conducted by Tohari et al by implementing STAD-type cooperative learning can improve student achievement (completeness) and learning activities (Tohari, Hanifah, and Jayadinata 2016). Other research also conducted by Sari STAD can 
improve Science Process Skills (KPS) and student physics learning outcomes (Sari 2016)

\section{CONCLUSIONS}

Based on the research results, it can be concluded that the application of STAD type cooperative learning with Hands on Activity can improve student learning outcomes and learning activities. The score of student activeness working on the LKPD reached an average value (100) in cycles I and II. The score of cooperative activeness increased from the low category (50) to the high category (70). The score for the activeness of expressing opinions increased from the medium category (53) to the high category (78). Student learning outcomes on elasticity material increased from $87 \%$ classical completeness to $91 \%$.

\section{ACKNOWLEDGMENTS}

The author would like to thank all those who helped, including: 1) Hamzanwadi University, for giving me an assignment to the school in the Lecturer Assignment program to School; 2) Drs. H. Masruri, as the principal of SMAN 1 Selong, who gave me the opportunity to teach in a school with good facilities. I got a lot of additional knowledge and experience from this activity.

\section{REFERENCES}

[1] Anggraeni and Dyah. 2009. "Penerapan Hands on Activity Dan Metode Example Non Example Dalam Pembelajaran Sel Dan Jaringan Tumbuhan Untuk Meningkatkan Aktivitas Dan Hasil Belajar Siswa Di SMA Diponegoro Tumpang / Dyah Anggraeni." Skripsi (Sarjana)--Universitas Negeri Malang. Jurusan Biologi 0(0).

[2] Anon. 2020. "Mengapa Kita Perlu Bekerjasama? Halaman All - Kompas.Com." Retrieved November 20, 2020 (https://www.kompas.com/skola/read/2020/08/03/ 171500969/mengapa-kita-perlu-bekerjasama?page $=$ all).

[3] Anonim. 2014. PENETAPAN KRITERIA KETUNTASAN MINIMAL.

[4] Anonim. 2016. "MODEL PEMBELAJARAN STAD | Model Pembelajaranku." Retrieved November 20, 2020 (https://modelpembelajaran1.wordpress.com/2016/ 02/20/model-pembelajaran-stad/).

[5] Anonim. 2018. "Cara Menentukan KKM Kurikulum 2013 Revisi 2018.” Guru Pengajar. Retrieved November 20, 2020 (https://gurupengajar.com/kkm-kurikulum-2013.html).

[6] Chaeruman, A. 2018. "PEMBELAJARAN ABAD 21." Seminar Nasional Pembelajaran Abad 21 Kemdikbud, April.

[7] Fathir, Muhammad and Sabrun Sabrun. 2015. "PENERAPAN MODEL PEMBELAJARAN KONTEKSTUAL BERBASIS HANDS ON
ACTIVITY PADA MATERI STATISTIKA UNTUK MENINGKATKAN MOTIVASI DAN HASIL BELAJAR SISWA.” Jurnal Ilmiah Mandala Education 1(2):131-39.

[8] Hariri, Ade Idrus. 2015. "Pembelajaran Berbasis Hands on Activity Pada Pembelajaran Sains Kontekstual." Acta Universitatis Agriculturae et Silviculturae Mendelianae Brunensis 16(2):39-55.

[9] Kemdikbud. 2013. "Kerangka Dasar Dan Struktur Kurikulum 2013." Kementrian Pendidikan Dan Kebudayaan, 1-21.

[10] Lovisia, Endang. 2019. "Penerapan Model Pembelajaran Kooperatif Tipe Studentteams Achievement Division (Stad) Pada Pembelajaran Fisika Siswa Kelas X Sma Negeri 7 Lubuklinggau." Silampari Jurnal Pendidikan Ilmu Fisika 1(1):1-12.

[11]Nurlatifah, Cica Aisyah. 2016. "Pengertian Model Pembelajaran Hands On Activity - Cica Aisyah Nurlatifah." Retrieved November 20, 2020 (http://cicaaisyahnurlatifah.blogspot.com/2016/11/ model-pembelajaran-hands-on-activity.html).

[12] Palupi, Retno. 2019. "Penerapan Kurikulum2013 Edisi Revisi 2017 Pada Pembelajaran Ekonomi." FLEPS 2019 - IEEE International Conference on Flexible and Printable Sensors and Systems, Proceedings 6(1):1-46.

[13] Riadi, Muchlisin. 2019. "Penelitian Tindakan Kelas (PTK) - KajianPustaka.Com.” Retrieved November 20, 2020 (https://www.kajianpustaka.com/2019/03/penelitia n-tindakan-kelas-ptk.html).

[14] Safitri, Ailis. 2020. "Pembelajaran Kolaborasi Gerakan Sekolah Menyenangkan." Retrieved November 20, 2020 (https://www.sekolahmenyenangkan.org/pembelaj aran-kolaborasi/).

[15] Sari, Happy Komike. 2016. "Peningkatan Keterampilan Proses Sains Dan Hasil Belajar Fisika Siswa Pada Model Pembelajaran Kooperatif Tipe Student Team Achievement Division." Tadris: Jurnal Keguruan Dan Ilmu Tarbiyah 1(1):15-22.

[16] Tohari, Egi Rizki, Nurdinah Hanifah, and Asep Kurnia Jayadinata. 2016. "Penerapan Model Pembelajaran Kooperatif Tipe Stad (Student Team Achievement Division) Melalui Permainan Tulis Kata Untuk Meningkatkan Hasil Belajar Siswa Pada Materi Jenis-Jenis Usaha Ekonomi.” Jurnal Pena Ilmiah 1(1):271-80.

[17] Trisnamansyah, Sutaryat. 2015. Evaluasi Pembelajaran. Vol. 5. Bandung.

[18] Wilhalminah A., Rahman, U. dan Muchisah. 2017. "Pengaruh Keterampilan Komunikasi Terhadap Perkembangan Moral Siswa Pada Mata Pelajaran." Biotek 5(2):37-52. 